\title{
Comparison of Spanish and Swedish Journal Indicators (Impact Factor and Self-citation Rate) in the Journal Citation Reports
}

\author{
By: Mohammad Hossein Biglu \\ mh_biglu@yahoo.com \\ and \\ Omid Askari
}

\begin{abstract}
The geographical and social differences between Spain and Sweden, two non-English language European countries, led to our review of the impact factors (IF) and self-citation rates of scientific journals published in these two countries. The study endeavours to compare the trends of citation rates and impact factors for all Spanish and Swedish journals indexed in the Journal Citation Reports during the time period 2000-2005.
\end{abstract}

\section{Introduction}

Using a map of Europe (Fig 1.: Appendix1), we see that Sweden, with a population of 9,016,596 and a constitutional monarchy, is located in northern Europe; on the opposite side of the continent, Spain is located in south-western Europe, with a population more than four times that of Sweden $(40,397,842)$ and a parliamentary monarchy. Besides geographical differences, there are social differences (Table 12) between the two countries that led to our interest in comparing certain indicators for these countries' scientific journals that are indexed in the Journal Citation Reports $(J C R)$.

A dominant research technique in library and information science, citation analysis is a wellknown method in bibliometric studies for measuring the influence and impact of scholarly journals. Consequently, it is used as a quantitative tool for ranking, evaluating, categorizing, and comparing journals by librarians and information scientists. This form of analysis goes back to a study conducted in 1927 by Gross and Gross who discovered that only a few journals were cited in the Journal of the American Chemical Society, and many were cited only once. Their findings have shown similarities with the power law. Characterised by the phenomenon that Merton (1968) described as the Matthew Effect, it is interpreted as "the rich get richer and the poor get poorer". On July 15, 1955, Eugene Garfield published his groundbreaking paper on citation indexing. In this paper he suggested that the Science Citation Index (SCI) would be a great asset in measuring impact and facilitating historiography. Since then we have witnessed an increasing use of citation 
analysis as an important tool in the hands of bibliometricians to determine the influence and impact of journals, authors, etc.

Researchers may use citation analysis for many reasons, including

to find out how much impact a particular article has had, by showing which other authors based some work upon it or cited it as an example within their own papers

to determine more about a field or topic (by reading the papers that cite a seminal work in that area)

to find out how much impact a particular author has had (by looking at his/her total citations). (Bieber \& Jacoby, 2002)

The tremendous growth of scientific literature, particularly in special fields in the scholarly world, and easy access to them cause researchers to use and cite more references in their works. Attempts among academic scientists and researchers to gain prestige may be another reason for the increase of the citation rate: authors can and do cite their prior work (self-citation).

High rate of author self-citation may result from the fact that authors stick to their specific field of research and, naturally, rely on their previous results...Self-citation of journals, especially in the SCI, is getting high and higher. Nearly every journal in the JCR-Science Edition contains at least some reference to its own. (Kovačic \& Mišak, 2004, np.)

Ken Hyland (2003) found that about 70\% of articles contained a reference to an earlier publication of at least one of the authors. In another study, Gami, Montori, Wilczynski. \& Haynes (2004) found that nearly one-fifth of all citations to articles about diabetes mellitus in clinical journals in the year 2000 were author self-citations. The frequency of self-citation was not associated with the quality of publications.

A study by Eugene Garfield (1979-80) based on information extracted from the SCI database found that, in terms of articles published, biochemical literature is growing faster than scientific literature as a whole. Garfield found that another growth indicator within the biochemical literature was the increase in the average number of references contained in a typical article. To examine this factor he developed an R/S value for each core journal. This is the number of 
references contained in all of a journal's issues during a specified year (R) divided by the number of source articles (S) it published that year. The study showed that the average biochemistry article contained at least $70 \%$ more references than the average article in the SCI database. For example, in 1977 the average biochemistry article contained 23.4 references as compared to the average of 13.5 references for those in the SCI; the R/S for SCI articles as a whole will be lower than the R/S for biochemistry articles. However, this situation could only account for a very small part of the $70 \%$ difference.

The study showed that the average R/S for the core journals had increased $10.4 \%$ in ten years, from 21.2 in 1968 to 23.4 in 1977. Over a 16-year period, however, the years 1962-1977, some of the CEBJ journals (journals whose editors are full members of the Committee of Editors of Biochemical Journals of the International Union of Biochemistry) (Garfield, 1979-80, pp. 414418) had increases in R/S as high as 64\% (Biochim. Biophys, Acta). On average, the R/S value for CEBJ journals increased by 43\% (18.2 to 26.1) from 1962 to 1977. As of 1977, biochemistry articles, on average, had $12 \%$ more references than botany articles ( 23.4 v. 21.0 ) and $85 \%$ more references than mathematics articles (23.4 v. 12.6). Mathematics and botany articles increased their R/S values by 8 and 7\% respectively between 1968 and 1977; these increases are substantially less than the $10.4 \%$ growth in the biochemistry R/S over the same period. Nevertheless, all three fields did show an increase in the number of references contained in an average article.

Garfield also found that biochemical literature is the fastest growing of any field in science. He asserted that some CEBJ journals have increased their average number of references per source item by as much as $64 \%$ in 16 years.

This study endeavours to determine the trend of citation, impact factor, and references per article for all Spanish and Swedish journals that were indexed in the JCR and to show the differences between them. The analysis of data indicates that there is a significant difference between the self-citing rate and the self-cited rate of journals in Spain as well as in Sweden throughout the period of study. 


\section{Method and Materials}

All journal self-citation and impact factor data were extracted from the 2000 and 2005 Journal Citation Reports (JCR). In order to determine the correlation between the Impact factor and selfcitation of journals, all journals from the two countries focused on in this study were chosen from the Journal Citation report of ISI web of knowledge available at http://portal.isiknowledge.com/portal.cgi?DestApp=JCR\&Func=Frame. The correlation between Impact factor and the rate of journals' self-citation were analysed by the software package of SPSS.

\section{Finding and Results}

\section{Table 1}

Distribution of journal self-citation rate in Spain (2000)

\begin{tabular}{|l|l|l|l|l|}
\hline \multirow{2}{*}{ Citation rate } & Self-cited & Self-citing \\
\cline { 2 - 5 } & No. of journals & Percent & No. of journals & Percent \\
\hline$<5 \%$ & 8 & 29 & 25 & 89 \\
\hline $5-10 \%$ & 5 & 18 & 3 & 11 \\
\hline $10-15 \%$ & 3 & 11 & - & 0 \\
\hline $15-20 \%$ & 1 & 4 & - & 0 \\
\hline$>20 \%$ & 11 & 39 & - & 0 \\
\hline Total & 28 & 100 & 28 & 100 \\
\hline
\end{tabular}

Table 1 illustrates the Spanish journals' distribution based on self-cited rate as well as self-citing rate. The table indicates that the largest self-citing group is that with the lowest self-cited rateless than 5\%-which accounts for 25 (44\%) of a total of 28 journals; the second largest group is that of journals with a citing rate of $5 \%$ to $10 \%$. These two groups constitute $100 \%$ of the 28 journals studied. For the self-cited statistic, the largest group is that with a rate higher than $20 \%$.

Table 2

Distribution of journal self-citation rate in Sweden (2000)

\begin{tabular}{|c|c|c|c|c|}
\hline \multirow[t]{2}{*}{ Citation rate } & \multicolumn{2}{|l|}{ Self-cited } & \multicolumn{2}{|l|}{ Self-citing } \\
\hline & No. of journals & Percent & No. of journals & Percent \\
\hline$<5 \%$ & 8 & 42 & 13 & 69 \\
\hline $5-10 \%$ & 5 & 26 & 5 & 26 \\
\hline $10-15 \%$ & - & 0 & 1 & 5 \\
\hline $15-20 \%$ & 3 & 16 & - & 0 \\
\hline$>20 \%$ & 3 & 16 & - & 0 \\
\hline Total & 19 & 100 & 19 & 100 \\
\hline
\end{tabular}


Table 2 shows the Swedish journals' distribution based on the 2000 self-cited and self-citing rates. The table indicates that the largest self-citing group is that with the self-cited rate-less than $5 \%$-which accounts for 13 (69\%) of the 19 journals. The second largest group is that with a citing-rate from $5 \%$ to $10 \%$. These two groups constitute about $95 \%$ of all studied Swedish journals. For the self-cited statistics, the large groups are the same as the two self-citing groups.

Table 3

Distribution of journal self-citation rate in Spain (2005)

\begin{tabular}{|l|l|l|l|l|}
\hline \multirow{2}{*}{ Citation rate } & Self-cited & Self-citing & Percent \\
\cline { 2 - 5 } & No. of journals & Percent & No. of journals & 60 \\
\hline$<5 \%$ & 9 & 30 & 18 & 33 \\
\hline $5-10 \%$ & 3 & 10 & 10 & 7 \\
\hline $10-15 \%$ & 1 & 3 & 2 & 0 \\
\hline $15-20 \%$ & 3 & 10 & - & 0 \\
\hline$>20 \%$ & 14 & 47 & - & 100 \\
\hline Total & 30 & 100 & 30 & \multicolumn{2}{l}{} \\
\hline
\end{tabular}

For 2005, the largest self-citing group is that with a self-cited rate of less than 5\%, which accounts for 18 (60\%) from a total of 30 journals; the second largest group is that with a citing rate of $5 \%$ to $10 \%$. These two groups constitute $93 \%$ of all studied Spanish journals. The largest self-cited group is that with a self-cite rate higher than $20 \%$.

\section{Table 4}

Distribution of journal self-citation rate in Sweden (2005)

\begin{tabular}{|l|l|l|l|l|}
\hline \multirow{2}{*}{ Citation rate } & Self-cited & Self-citing \\
\cline { 2 - 5 } & No. of journals & Percent & No. of journals & Percent \\
\hline$<5 \%$ & 3 & 17 & 10 & 56 \\
\hline $5-10 \%$ & 8 & 44 & 8 & 44 \\
\hline $10-15 \%$ & 4 & 22 & - & 0 \\
\hline $15-20 \%$ & 2 & 11 & - & 0 \\
\hline$>20 \%$ & 1 & 6 & - & 0 \\
\hline Total & 18 & 100 & 18 & 100 \\
\hline
\end{tabular}

For 2005, the largest group in the self-citing column is that with a self-citing rate of below $10 \%$. There is no journal with a self-citing rate higher than $10 \%$ in this group. 
Figure 2: Difference of Spanish journals' IF (2005-2000)

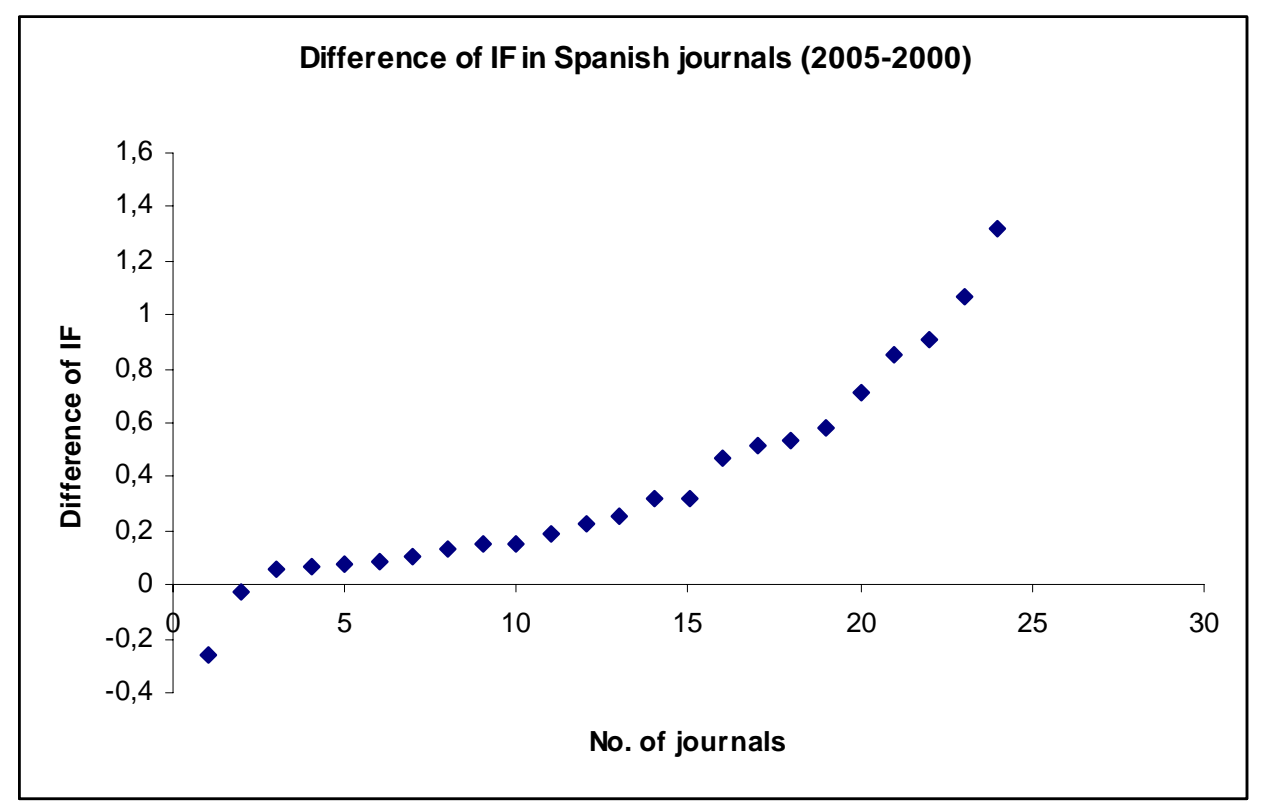

Comparing the IF for Spanish journals in 2000 and in 2005 in the same set of journals indicates that the IF is higher for 91.6\% of Spanish journals in 2005 than in 2000.

Figure 3: Difference of Swedish journals' IF (2005-2000) 


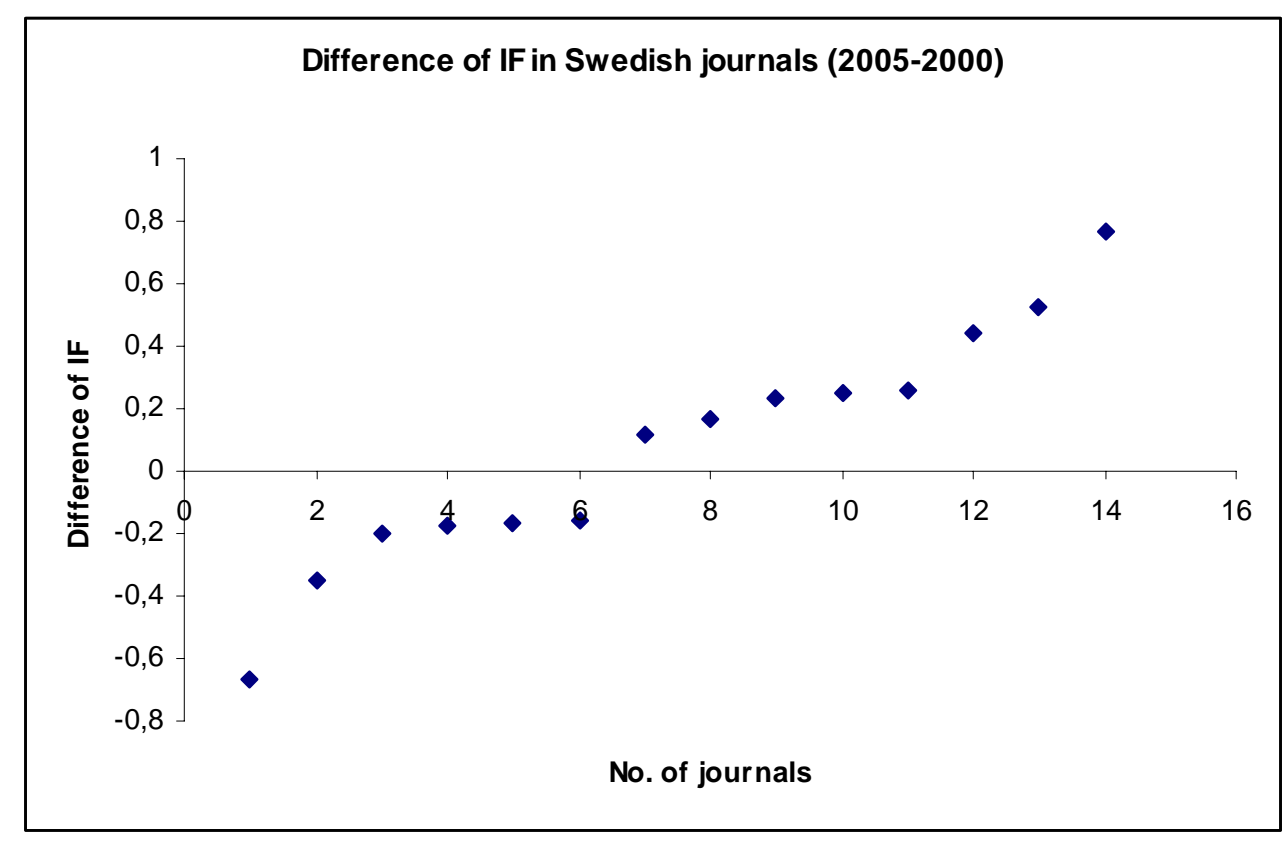

Comparing Figure 2 with Figure 3 indicates that Spanish journals are more productive than Swedish journals in the same period of study. As the graph illustrates, the IF for $50 \%$ of the Swedish journals in 2005 compared to the IF for the same set of journals in 2000 increased while the IF for the other $50 \%$ in the same set of journals decreased. This indicates that there was no significant growth in the IF for the Swedish journals for the time period studied.

Figure 4: The relation of journal self-citing to self-cited for Spanish journals in 2005

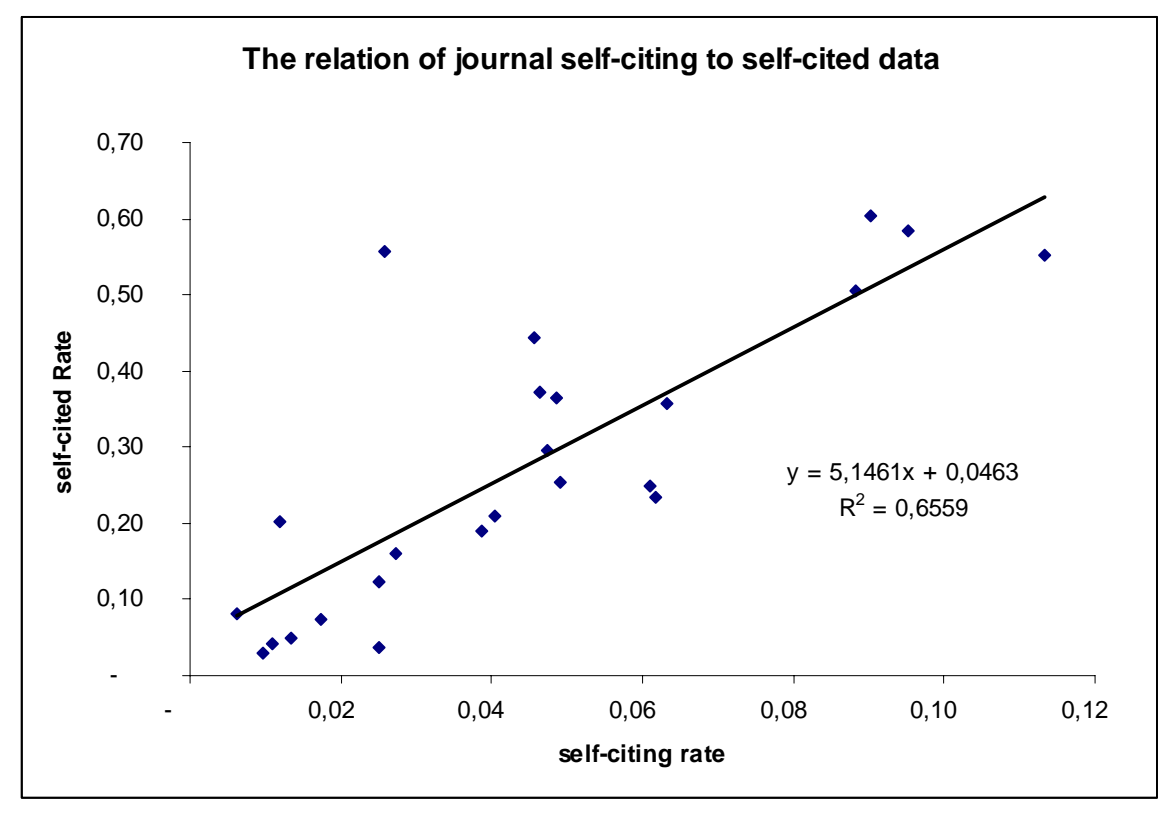


As the graph illustrates, there is a linear correlation between Spanish journal self-citing and selfcited values. The graph indicates that the more Spanish journals are citing their own, the more they are being cited by a factor of 5.15 .

Figure 5: The relation of Swedish journals' self-citing and self-cited rate in 2005.

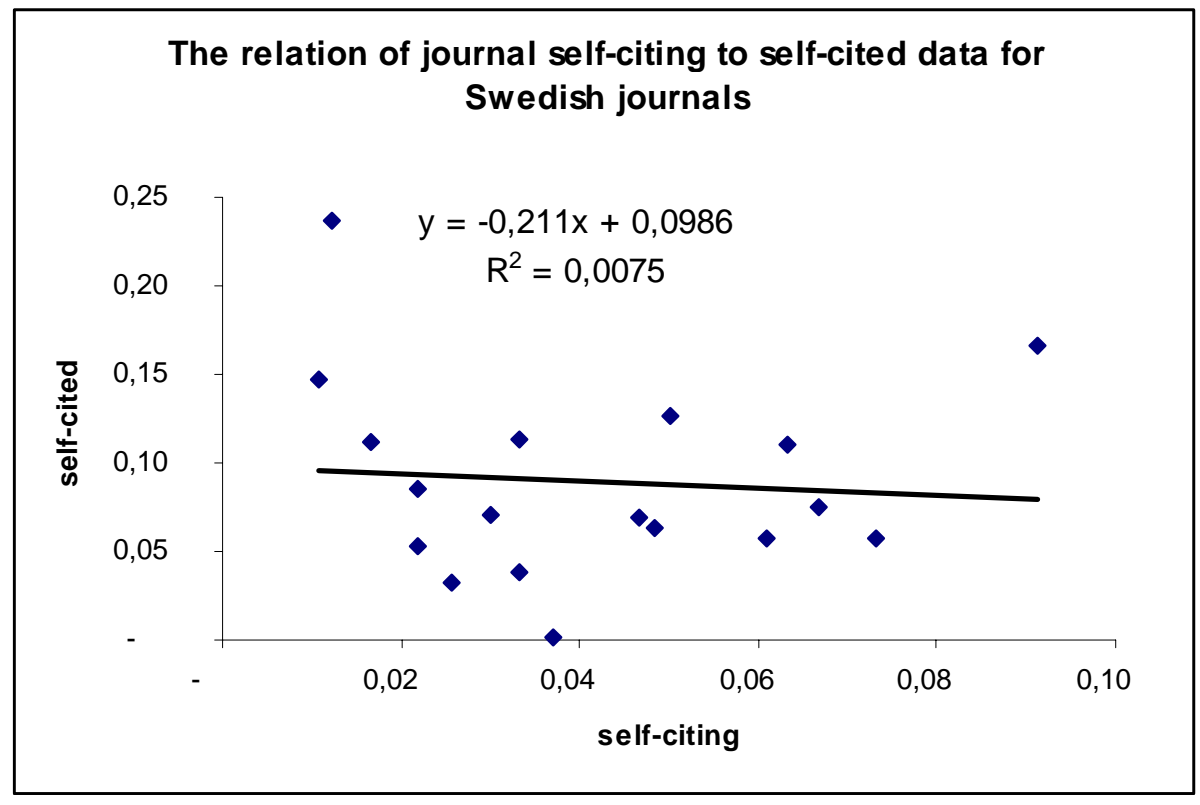

The graph illustrates that the more Swedish journals cite themselves the less they are cited. 
Table 5

Number of articles and references for Spanish journals 2000-2005

\begin{tabular}{|l|l|l|l|}
\hline Year & No. of articles & No. of references & Mean value of references per article \\
\hline 2000 & 2329 & 95093 & 40.82 \\
\hline 2005 & 1998 & 98692 & 49.39 \\
\hline
\end{tabular}

As Table 5 shows, the number of references per article in Spanish journals increased about 1.7 references per article annually.

Table 6

Number of articles and references for Swedish journals 2000-2005

\begin{tabular}{|c|c|c|c|}
\hline Year & No. of articles & No. of references & Mean value of references per article \\
\hline 2000 & 1210 & 35931 & 29.69 \\
\hline 2005 & 1151 & 37609 & 32.67 \\
\hline
\end{tabular}

As Table 6 indicates, the number of references per article in Swedish journals increased about 0.6 references per article annually.

Table 7

List of Swedish journals based on self-citing rank (2000)

\begin{tabular}{|c|l|c|c|c|c|}
\hline Rank & \multicolumn{1}{|c|}{ Journal titles (abbreviated) } & $\begin{array}{c}\text { Impact } \\
\text { factor }\end{array}$ & Total citation & Self-cited rate & Self-citing rate \\
\hline 1 & TELLUS B & 3.256 & 1984 & 0.2 & 0.14 \\
\hline 2 & GEOGR ANN A & 0.868 & 522 & 0.17 & 0.09 \\
\hline 3 & NORD PULP PAPER RES & 0.759 & 384 & 0.25 & 0.09 \\
\hline 4 & SWED DENT J & 0.914 & 561 & 0.07 & 0.09 \\
\hline 5 & J VEG SCI & 1.589 & 1924 & 0.16 & 0.08 \\
\hline 6 & TELLUS A & 1.178 & 1032 & 0.05 & 0.05 \\
\hline 7 & ACTA PHYSIOL SCAND & 1.764 & 7707 & 0.03 & 0.04 \\
\hline 8 & ACTA RADIOL & 0.785 & 2343 & 0.03 & 0.04 \\
\hline 9 & HEREDITAS & 0.753 & 1392 & 0.05 & 0.04 \\
\hline 10 & PHYS SCRIPTA & 0.578 & 4078 & 0.08 & 0.04 \\
\hline 11 & AMBIO & 1.142 & 2109 & 0.04 & 0.03 \\
\hline 12 & GFF & 0.756 & 200 & 0.26 & 0.03 \\
\hline 13 & SCAND J METALL & 0.074 & 292 & 0.07 & 0.03 \\
\hline 14 & SCAND J STAT & 0.655 & 634 & 0.04 & 0.03 \\
\hline 15 & J NONLINEAR MATH PHY & 0.250 & 39 & 0.23 & 0.01 \\
\hline 16 & ACTA MATH-DJURSHOLM & 1.941 & 1637 & 0.00 & 0.00 \\
\hline 17 & ARK MAT & 0.511 & 357 & 0.00 & 0.00 \\
\hline 18 & SCAND J SOC MED & 1.250 & 517 & 0.00 & 0.00 \\
\hline 19 & SWED J AGR RES & 0.238 & 247 & 0.00 & 0.00 \\
\hline
\end{tabular}

This table indicates that the journal Tellus Series B: Chemical and Physical Meteorology ranked first in self-citing in 2000. The mean self-cited rate is $9 \%$ and the mean self-citing rate is $5 \%$. 
Table 8

\section{List of Swedish journals based on self-citing rank (2005)}

\begin{tabular}{|l|l|r|r|r|r|}
\hline Rank & Journal titles (abbreviated) & Impact factor & Total citation & Self-cited rate & Self-citing rate \\
\hline 1 & NORD PULP PAP RES J & 0.600 & 798 & 0.17 & 0.09 \\
\hline 2 & J VEG SCI & 2.112 & 3370 & 0.08 & 0.07 \\
\hline 3 & TELLUS B & 2.592 & 2052 & 0.06 & 0.07 \\
\hline 4 & SWED DENT J & 0.568 & 558 & 0.06 & 0.06 \\
\hline 5 & TELLUS A & 1.947 & 1144 & 0.11 & 0.06 \\
\hline 6 & AMBIO & 1.378 & 2609 & 0.07 & 0.05 \\
\hline 7 & GEOGR ANN A & 0.667 & 753 & 0.13 & 0.05 \\
\hline 8 & PHYS SCRIPTA & 1.240 & 4057 & 0.06 & 0.05 \\
\hline 9 & ACTA MATH-DJURSHOLM & 1.778 & 1934 & 0.00 & 0.04 \\
\hline 10 & ACTA RADIOL & 1.031 & 2379 & 0.03 & 0.03 \\
\hline 11 & APPL VEG SCI & 1.517 & 319 & 0.11 & 0.03 \\
\hline 12 & SCAND J METALL & 0.517 & 365 & 0.07 & 0.03 \\
\hline 13 & SCAND J STAT & 0.822 & 914 & 0.04 & 0.03 \\
\hline 14 & ARK MAT & 0.628 & 415 & 0.05 & 0.02 \\
\hline 15 & J REHABIL MED & 1.799 & 455 & 0.09 & 0.02 \\
\hline 16 & NEUROENDOCRINOL LETT & 1.005 & 614 & 0.11 & 0.02 \\
\hline 17 & GFF & 0.581 & 80 & 0.24 & 0.01 \\
\hline 18 & J NONLINEAR MATH PHY & 0.508 & 190 & 0.15 & 0.01 \\
\hline
\end{tabular}

Table 8 shows that the journal Nordic Pulp \& Paper Research with a 9\% self-citing rate ranked first in 2005 and the journal Tellus Series B: Chemical and Physical Meteorology was lowered to third rank.

In 2005, the mean self-cited rate was $9 \%$, and the mean self-citing rate was $4 \%$.

Table 9

List of Spanish journals based on self-citing rank (2000)

\begin{tabular}{|c|c|c|c|c|c|}
\hline No. & Journal titles (abbreviated) & Impact factor & Total citation & $\begin{array}{l}\text { Self-cited } \\
\text { rate }\end{array}$ & $\begin{array}{l}\text { Self-citing } \\
\text { rate }\end{array}$ \\
\hline 1 & REV ESP CARDIOL & 0.700 & 683 & 0.73 & 0.07 \\
\hline 2 & MED CLIN-BARCELONA & 0.750 & 1628 & 0.42 & 0.06 \\
\hline 3 & NEFROLOGIA & 0.310 & 277 & 0.68 & 0.05 \\
\hline 4 & GRASAS ACEITES & 0.453 & 343 & 0.20 & 0.04 \\
\hline 5 & REV ESP ENFERM DIG & 0.384 & 308 & 0.27 & 0.04 \\
\hline 6 & MATER CONSTRUCC & 0.219 & 28 & 0.46 & 0.03 \\
\hline 7 & REV MAT IBEROAM & 0.750 & 239 & 0.05 & 0.03 \\
\hline 8 & REV METAL MADRID & 0.190 & 54 & 0.41 & 0.03 \\
\hline 9 & INT J DEV BIOL & 1.963 & 1594 & 0.06 & 0.02 \\
\hline 10 & REV CLIN ESP & 0.217 & 411 & 0.14 & 0.02 \\
\hline 11 & SCI MAR & 0.521 & 516 & 0.16 & 0.02 \\
\hline 12 & AFINIDAD & 0.152 & 95 & 0.15 & 0.01 \\
\hline 13 & BOL SOC ESP CERAM V & 0.099 & 56 & 0.36 & 0.01 \\
\hline 14 & HISTOL HISTOPATHOL & 1.553 & 1246 & 0.07 & 0.01 \\
\hline 15 & J INVEST ALLERG CLIN & 0.537 & 279 & 0.05 & 0.01 \\
\hline 16 & J PHYSIOL BIOCHEM & 0.958 & 85 & 0.11 & 0.01 \\
\hline 17 & METHOD FIND EXP CLIN & 0.543 & 675 & 0.04 & 0.01 \\
\hline 18 & NEUROCIRUGIA & 0.154 & 41 & 0.56 & 0.01 \\
\hline
\end{tabular}




\begin{tabular}{|c|c|c|c|c|c|}
\hline 19 & REV NEUROLOGIA & 0.256 & 339 & 0.67 & 0.01 \\
\hline 20 & TEST & 0.308 & 52 & 0.08 & 0.01 \\
\hline 21 & DRUG FUTURE & 0.015 & 16 & - & - \\
\hline 22 & QUIM ANAL & 0.246 & 183 & - & - \\
\hline 23 & ACTAS LUSO-ESP NEUR & 0.302 & 80 & - & - \\
\hline 24 & AN QUIM-INT ED & 0.312 & 331 & - & - \\
\hline 25 & ACTAS ESP PSIQUIATRI & 0.098 & 5 & 0.4 & 0 \\
\hline 26 & ARCH COMPUT METHOD E & 0.688 & 87 & 0.01 & 0 \\
\hline 27 & DRUG NEWS PERSPECT & 0.835 & 256 & 0.01 & 0 \\
\hline 28 & DRUGS TODAY & 0.339 & 273 & 0.04 & 0 \\
\hline
\end{tabular}

Table 9 illustrates that the journal Revista espanola de Cardiologia with a 7\% self-citing rate ranked first among Spanish journals in 2000. The mean self-cited rate was 22\%, and the mean self-citing rate was $2 \%$.

Table 10

List of Spanish journals based on self-citing rank (2005)

\begin{tabular}{|c|c|c|c|c|c|}
\hline Rank & Journal titles (abbreviated) & $\begin{array}{l}\text { Impact } \\
\text { factor }\end{array}$ & Total citation & Self-cited rate & Self-citing rate \\
\hline 1 & REV METAL MADRID & 0.414 & 152 & 0.55 & 0.11 \\
\hline 2 & ARCH BRONCONEUMOL & 1.401 & 660 & 0.58 & 0.1 \\
\hline 3 & BOL SOC ESP CERAM V & 0.684 & 287 & 0.6 & 0.09 \\
\hline 4 & REV ESP CARDIOL & 1.769 & 993 & 0.5 & 0.09 \\
\hline 5 & GRASAS ACEITES & 0.194 & 426 & 0.25 & 0.06 \\
\hline 6 & MATER CONSTRUCC & 0.542 & 98 & 0.23 & 0.06 \\
\hline 7 & MED CLIN-BARCELONA & 1.074 & 2084 & 0.36 & 0.06 \\
\hline 8 & ARDEOLA & 0.509 & 219 & 0.37 & 0.05 \\
\hline 9 & ENFERM INFEC MICR CL & 0.905 & 550 & 0.29 & 0.05 \\
\hline 10 & NEFROLOGIA & 0.466 & 390 & 0.44 & 0.05 \\
\hline 11 & REV ESP ENFERM DIG & 0.535 & 365 & 0.25 & 0.05 \\
\hline 12 & REV NEUROLOGIA & 0.391 & 1157 & 0.37 & 0.05 \\
\hline 13 & NEUROLOGIA & 0.571 & 416 & 0.21 & 0.04 \\
\hline 14 & SCI MAR & 1.036 & 1247 & 0.19 & 0.04 \\
\hline 15 & J PHYSIOL BIOCHEM & 0.934 & 177 & 0.12 & 0.03 \\
\hline 16 & NEUROCIRUGIA & 0.232 & 104 & 0.56 & 0.03 \\
\hline 17 & REV CLIN ESP & 0.273 & 428 & 0.16 & 0.03 \\
\hline 18 & REV MAT IBEROAM & 0.855 & 367 & 0.04 & 0.03 \\
\hline 19 & INT MICROBIOL & 1.868 & 337 & 0.07 & 0.02 \\
\hline
\end{tabular}




\begin{tabular}{|c|c|c|c|c|c|}
\hline 20 & ACTAS ESP PSIQUIATRI & 0.286 & 109 & 0.2 & 0.01 \\
\hline 21 & AFINIDAD & 0.220 & 148 & 0.08 & 0.01 \\
\hline 22 & HISTOL HISTOPATHOL & 2.023 & 2152 & 0.05 & 0.01 \\
\hline 23 & INT J DEV BIOL & 2.051 & 2258 & 0.03 & 0.01 \\
\hline 24 & TEST & 1.163 & 163 & 0.04 & 0.01 \\
\hline 25 & ARCH COMPUT METHOD E & 1.400 & 122 & - & - \\
\hline 26 & DRUG FUTURE & 0.547 & 355 & 0.01 & 0 \\
\hline 27 & DRUG NEWS PERSPECT & 2.159 & 516 & 0.02 & 0 \\
\hline 28 & DRUGS TODAY & 1.248 & 592 & 0.01 & 0 \\
\hline 29 & METHOD FIND EXP CLIN & 0.798 & 823 & 0.01 & 0 \\
\hline 30 & PUBL MAT & 0.659 & 129 & - & - \\
\hline
\end{tabular}

The journal Revista de Metalurgia, with a 6\% self-citing rate, rose to the first rank among Spanish journals in 2005, and the journal Revista espanola de Cardiologia fell to fourth rank. The mean self-cited rate was $22 \%$, and the mean self-citing rate was $4 \%$.

\section{Table 11}

The portion of Spanish and Swedish journals entering material in the JCR data bank in 2005

\begin{tabular}{|l|l|l|l|l|l|l|}
\hline Origin of journals & $\begin{array}{l}\text { No. of } \\
\text { journal }\end{array}$ & percent & Articles & percent & Citations & percent \\
\hline Spanish journals in the JCR & 30 & $0.5 \%$ & 1,151 & $0.1 \%$ & 17,824 & $0.08 \%$ \\
\hline Swedish journals in the JCR & 19 & $0.3 \%$ & 1,998 & $0.2 \%$ & 23,006 & $0.10 \%$ \\
\hline All journals in the JCR & 6,088 & $100.0 \%$ & 847,114 & $100.0 \%$ & $22,353,992$ & $100.00 \%$ \\
\hline
\end{tabular}

Reverse order of highlighted items. Statistics must be wrong.

Table 11 illustrates that from a total number of 6,088 journals in the JCR in 2005, $30(0.5 \%)$ were published in Spain, and 19 (0.3\%) were published in Sweden. The 6,088 journals in the JCR produced 847,114 articles, 1,998 (0.2\%) appeared in Swedish journals and 1,151 (0.1\%) in Spanish journals. Of the 22,353,992 citations in 2005, 23,006 (0.10\%) came from Swedish journals and 17,824 (0.08\%) from Spanish journals.

Table 12

\section{Geographical and social differences between Spain and Sweden ${ }^{\mathrm{i}}$}

\begin{tabular}{|l|l|l|}
\hline & \multicolumn{1}{|c|}{ Spain } & \multicolumn{1}{|c|}{ Sweden } \\
\hline Location & $\begin{array}{l}\text { South-western Europe, bordering the Bay of } \\
\text { Biscay, Mediterranean Sea, North Atlantic Ocean, } \\
\text { and Pyrenees Mountains, southwest of France }\end{array}$ & $\begin{array}{l}\text { Northern Europe, bordering the Baltic Sea, } \\
\text { Gulf of Bothnia, Kattegat, and Skagerrak, } \\
\text { between Finland and Norway }\end{array}$ \\
\hline Area & $\begin{array}{l}\text { total: } 504,782 \mathrm{sq} \mathrm{km} \\
\text { land: 499,542 sq km } \\
\text { water: 5,240 sq km }\end{array}$ & $\begin{array}{l}\text { total: 449,964 sq km } \\
\text { land: 410,934 sq km } \\
\text { water: 39,030 sq km }\end{array}$ \\
\hline Climate & $\begin{array}{l}\text { temperate; clear, hot summers in interior, more } \\
\text { moderate and cloudy along coast; cloudy, cold } \\
\text { winters in interior, partly cloudy and cool along } \\
\text { coast }\end{array}$ & $\begin{array}{l}\text { temperate; in south with cold, cloudy winters } \\
\text { and cool, partly cloudy summers; subarctic in } \\
\text { north }\end{array}$ \\
\hline Natural resources & $\begin{array}{l}\text { coal, lignite, iron ore, copper, lead, zinc, uranium, } \\
\text { tungsten, mercury, pyrites, magnesite, fluorspar, } \\
\text { gypsum, sepiolite, kaolin, potash, hydropower, } \\
\text { arable land }\end{array}$ & $\begin{array}{l}\text { iron ore, copper, lead, zinc, gold, silver, } \\
\text { tungsten, uranium, arsenic, feldspar, timber, } \\
\text { hydropower }\end{array}$ \\
\hline Population growth rate & $0.13 \%$ (2006 est.) & - \\
\hline
\end{tabular}




\begin{tabular}{|c|c|c|}
\hline Birth rate & 10.06 births/1,000 population (2006 est.) & 10.27 births/1,000 population (2006 est.) \\
\hline HIV/AIDS - deaths & 9.72 deaths/1,000 population (2006 est.) & less than 100 (2003 est.) \\
\hline Sex rate & $\begin{array}{l}\text { At birth: } 1.07 \text { male(s)/female } \\
\text { under } 15 \text { years: } 1.06 \text { male(s)/female } \\
\text { 15-64 years: } 1.01 \text { male(s)/female } \\
65 \text { years and over: } 0.72 \text { male(s)/female } \\
\text { total population: } 0.96 \text { male(s)/female (2006 est.) }\end{array}$ & $\begin{array}{l}\text { At birth: } 1.06 \text { male(s)/female } \\
\text { under } 15 \text { years: } 1.06 \text { male(s)/female } \\
\text { 15-64 years: } 1.03 \text { male(s)/female } \\
65 \text { years and over: } 0.77 \text { male(s)/female } \\
\text { total population: } 0.98 \text { male(s)/female (2006 } \\
\text { est.) }\end{array}$ \\
\hline Life expectancy at birth & $\begin{array}{l}\text { Total population: } 79.65 \text { years } \\
\text { male: } 76.32 \text { years } \\
\text { female: } 83.2 \text { years ( } 2006 \text { est.) }\end{array}$ & $\begin{array}{l}\text { Total population: } 80.51 \text { years } \\
\text { male: } 78.29 \text { years } \\
\text { female: } 82.87 \text { years (2006 est.) }\end{array}$ \\
\hline $\begin{array}{l}\text { people living with } \\
\text { HIV/AIDS }\end{array}$ & 140,000 (2001 est.) & 3,600 (2001 est.) \\
\hline Religion & Roman Catholic 94\%, other 6\% & $\begin{array}{l}\text { Lutheran 87\%, Roman Catholic, Orthodox, } \\
\text { Baptist, Muslim, Jewish, Buddhist }\end{array}$ \\
\hline Language & $\begin{array}{l}\text { Castilian Spanish } 74 \% \text {, Catalan } 17 \% \text {, Galician } 7 \% \text {, } \\
\text { Basque } 2 \% \text {; note - Castilian is the official language } \\
\text { nationwide; the other languages are official } \\
\text { regionally }\end{array}$ & $\begin{array}{l}\text { Swedish, small Sami- and Finnish-speaking } \\
\text { minorities }\end{array}$ \\
\hline GDP - real growth rate & $3.5 \%$ (2005 est.) & $2.7 \%$ (2005 est.) \\
\hline
\end{tabular}

\section{Conclusion}

In spite of significant geographical and social differences between Spain and Sweden (Table 12), there are similarities in journals’ indicators published in these two European countries.

From a total number of 6,088 journals in the JCR in 2005, 30 (0.5\%) were published in Spain, and 19 (0.3\%) were published in Sweden. The 6,088 journals in the JCR produced 847,114 articles, 1,998 (0.2\%) appeared in Swedish journals and 1,151 (0.1\%) in Spanish journals. Of the 22,353,992 citations in 2005, 23,006 (0.10\%) came from Swedish journals and 17,824 (0.08\%) from Spanish journals.

We have noticed that 4 journals from a total of 28 journals published in 2000 in Spain were cancelled in 2005 and 6 new journals published in 2006, and 5 journals from a total 19 journals published in 2000 in Sweden were cancelled and 5 new journals published in 2005.

The comparison of Spanish journals with Swedish journals for the 2000-2005 period showed that the mean value of references per article in Spanish journals is higher than in Swedish journals: 40.82 in 2000 and 49.39 in 2005 respectively for Spanish journals versus 29.69 in 2000 and 32.67 in 2005 for Swedish journals.

The study showed that there is a significant difference between the self-citing rate and the selfcited rate of journals in Spain as well as in Sweden throughout the period of study. Analysis of data indicated that the more the Spanish journals cite themselves, the more tend to be cited 
(Figure 4). The IF of Spanish journals in 2005 showed significant growth in comparison to the same set of journals in 2000. Such differences were not found among Swedish journals, however.

\section{References}

Bieber, M., \& Jacoby. (2002). Information system principles. Retrieved December 16, 2006, from http://web.njit.edu/ bieber/CIS677S02/citation-analysis.html\#science-search

Central Intelligence Agency. The world fact book. Retrieved December 2, 2006, from https://cia.gov/cia//publications/factbook

Gami, A.S., Montori, V. M., Wilczynski, N. L., \& Haynes, R. B. (2004, June 22). Author selfcitation in the diabetes literature. CMAJ, 170(13), 1925-1927. Retrieved September 7, 2006, from http://www.pubmedcentral.nih.gov/articlerender.fcgi?artid=421720

Garfield, E. (1955, July 15). Citation Indexes for science: A new dimension in documentation through association of ideas. Science, 122(3159), 108-111. Retrieved September 7, 2006, from http://www.garfield.library.upenn.edu/papers/science_v122v3159p108y1955.html

Garfield E. (1979-80). The number of biochemical articles is growing, but why? Also the number of references per article? Essays of an Information Scientist, 4, 414-418. Retrieved September 19, 2006, from http://www.garfield.library.upenn.edu/essays/v4p414y197980.pdf\#search=\%22CEBJ\%20biochemical\%20\%20journals\%22

Garfield E. (1979-80). Trends in biochemical literature. Essays of an Information Scientist, 4, 419-425.

Gross, P. L. K., \& Gross, E. M. (1927). College libraries and chemical education. Science, 66, 385-389.

Hyland, K. (2003, February 1). Self-citation and self-reference: Credibility and promotion in academic publication. Journal of the American Society for Information Science and Technology, 54(3), 251-259. Retrieved December 4, 2006, from http://www3.interscience.wiley.com/cgi-bin/fulltext/102523280/PDFSTART

Kovå̌ić, N., \& Mišak, A. (2004, June 22). Author self-citation in medical literature. CMAJ, 170(13), doi:10.1503/cmaj.1040513. Retrieved September 2006 from http://www.cmaj.ca/cgi/content/full/170/13/1929

McVeigh, M. E. (2002), Journal self-citation in the Journal Citation Reports - Science edition. Retrieved December 7, 2006, from http://scientific.thomson.com/free/essays/journalcitationreports/selfcitation2002/. 
Merton, R. K. (1968, January 5). Matthew Effect in science. Science, 159(3810), 56-63.

Retrieved September 4, 2006, from

http://www.garfield.library.upenn.edu/merton/matthew1.pdf\#search=\%22Robert\%20K.\% 20Merton\%20matthew\%20effect $\% 22$

Appendix 1: Fig 1

The European countries map

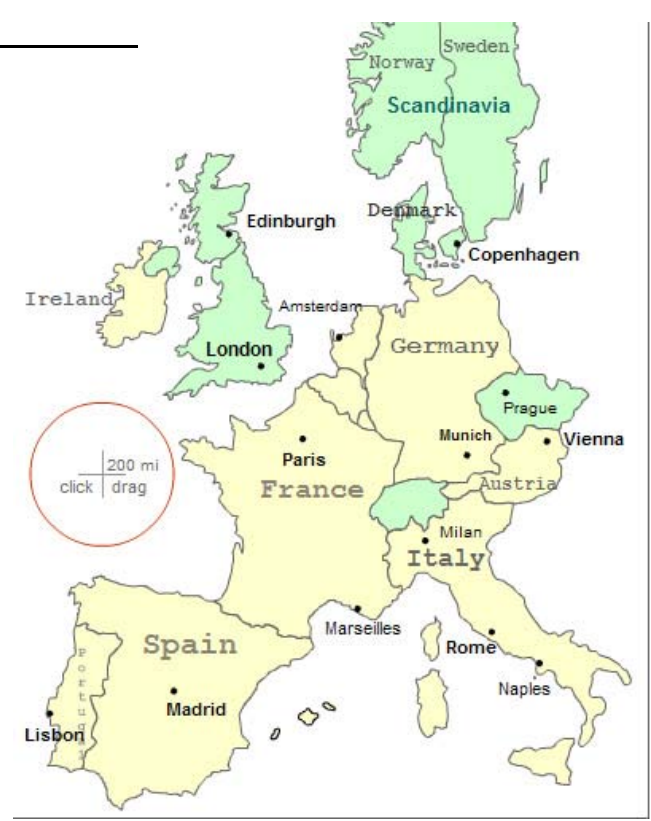

